\title{
The Behavior of Lux-marked Ralstonia solanacearum in Grafted Tomato Cultivars Resistant or Susceptible to Bacterial Wilt
}

\author{
Yasufumi HIKICHI*, Yoshiko NAKAZAWA-NASU**,***, Shinobu KitAnOSONO*, \\ Kazumi SUZUKI** and Tetsuro OKUNO*
}

\begin{abstract}
Ralstonia solanacearum OE1-1 was transformed with pNP126 carrying a luxCDABE operon of Vibrio fisheri and a promoter region derived from the genomic DNA of Burkholderia glumae. Intensity of bioluminescence from YN5 thus obtained positively correlated with growth of the bacteria from the lag phase to the stationary phase in vitro. In this study, we used the VIM camera equipped with the ARGUS 50 to successively observe bioluminescence and the development of bacterial wilt in singly and doubly grafted tomato plants in various combinations of the resistant LS-89 and the susceptible Oogata-Fukuju. The degree of bacterial growth in the roots and collars was one of the determinants for the induction of bacterial wilt in tomato plants. Resistance of LS-89 resulted from suppression of bacterial proliferation in the roots and stems below the first leaf. In grafted tomato plants using LS-89 as the rootstock, all rootstocks were latently infected with the bacteria. The bacteria were also recovered from susceptible scions even though the plants did not wilt. In some plants, the bacteria proliferated in the susceptible scions. These plants wilted heavily. Taken together, suppression of bacterial proliferation in the roots and the stems below the first leaf of resistant rootstocks affected the bacterial growth in the susceptible scions and quantative control of resistance against development of the disease.
\end{abstract}

(Received March 8, 1999 ; Accepted September 20, 1999)

Key words : Ralstonia solanacearum, bacterial wilt of tomato, grafted tomato plants, LS-89.

\section{INTRODUCTION}

Bacterial wilt caused by Ralstonia solanacearum (synonym Pseudomonas solanacearum) (Smith) Smith, is one of the most devastating bacterial plant diseases of tomato in the tropics, subtropics, and warm temperature regions worldwide ${ }^{8}$. The bacterium invades plant vascular tissues from wounded roots or natural openings from which secondary roots subsequently emerge ${ }^{11,211}$. Bacterial colonization in the stems results in browning of the xylem, foliar epinasty and a lethal, generalized wilt ${ }^{11}$.

Control of the disease with chemicals is mostly ineffective or is not adapted to low-income farming systems $^{3}$. For the control of the disease in Japan, the soil must be sterilized by solarization or with chemicals such as methyl bromide or chlorpicrin, either independently or in combination ${ }^{14)}$. However, soil sterilization does not completely control the disease because chemicals are absorbed by soil particles and degraded by microorganisms.

The use of resistant varieties of tomato is the most effective means for the control of the disease, but no fresh market varieties of tomato possess both high resistance and high fruit quality. So grafting tomato cultivars susceptible to bacterial wilt onto resistant rootstocks is a means to control the disease ${ }^{1,14,18,24,25}$. However, susceptible scions grafted onto resistant rootstocks often wilt in fields ${ }^{5,8,14,16)}$. The degree of disease resistance is inversely related to the spread of $R$. solanacearum in the stem tissues, ${ }^{4,19)}$, which is limited in the vascular tissues of resistant tomato cultivars. Nakaho ${ }^{15}$ ) has further suggested that the horizontal spread of pathogen from the protoxylem or primary xylem tissues to other xylem tissues is limited in resistant cultivars.

The lux genes have been successfully expressed in diverse bacteria; thus, the bioluminescence detection technique would have broad applicability in the study of the behavior of both rhizosphere and epiphytic bacteria $^{9,10,20,22)}$. Luminescence-marker systems have now been used for environmental detection of a wide range of microorganism in soil and plants. Only living bacterial cells with introduced lux genes can produce

* Laboratory of Plant Pathology and Biotechnology, Faculty of Agriculture, Kochi University, Nankoku 783-8502, Japan 高知大学農学部

** Iwate Biotechnology Research Center, Kitakami 024-0003, Japan＼cjkstart財団法人岩手生物工学研究センター

*** Present address : Tochigi Prefectural Agricultural Experimental Station, Utsunomiya 320-0002, Japan 農業試験場

現在：栃木県 
bioluminescence, because the production of the substrate for the enzymatic reaction requires active electron transfer ${ }^{20)}$.

Luciferase and reductase are the key enzymes required for bioluminescence. The intensity of bioluminescence is strongly dependent on the cellular level of ATP to recycle tetradecanal, the luciferin for light production. However, in previous studies using X-ray films and the CCD camera, obtaining images of bacterial bioluminescence in a short time and measuring bacterial density quantitatively was difficult. The use of a videointensified microscopy (VIM) camera results in detecting single photons in a short time, and excitation light is unnecessary to observe the bioluminescence ${ }^{7,9,10,12,23)}$.

We previously observed the growth and movement of $P$. cichorii transformed with pNP126 containing a lux $C D A B E$ operon and a promoter region derived from genomic DNA of Burkholderia glumae in lettuce leaf with the VIM camera equipped with the ARGUS $50^{10}$. We found that bacterial rot followed bacterial multiplication in the intercellular spaces of the epidermis and mesophyll and bacterial movement through the vascular bundle in the lettuce leaf. Disease development also required de novo protein synthesis in the tissues.

In this study, we used a VIM camera equipped with the ARGUS 50 to successively observe bioluminescence over time along with the development of bacterial wilt in singly grafted and doubly grafted tomato plants in various combinations of the resistant LS-89 and the susceptible Oogata-Fukuju. We also discuss the relationship between bacterial proliferation and disease development in tomato plants.

\section{MATERIALS AND METHODS}

Plants Seeds of a susceptible tomato (Lycopersicum esculentum) cultivar, Oogata-Fukuju (OF), and a resistant tomato cultivar, LS-89 (LS), a selection from Hawaii $7998^{28)}$, were purchased from Takii \& Co., Ltd. Tomato seedlings were grown in soil (Compal, Sumitomo Forestry) in a nursery box $(550 \mathrm{~mm} \times 300 \mathrm{~mm}$, 50 holes/box) in a greenhouse under $25 \pm 5^{\circ} \mathrm{C}$.

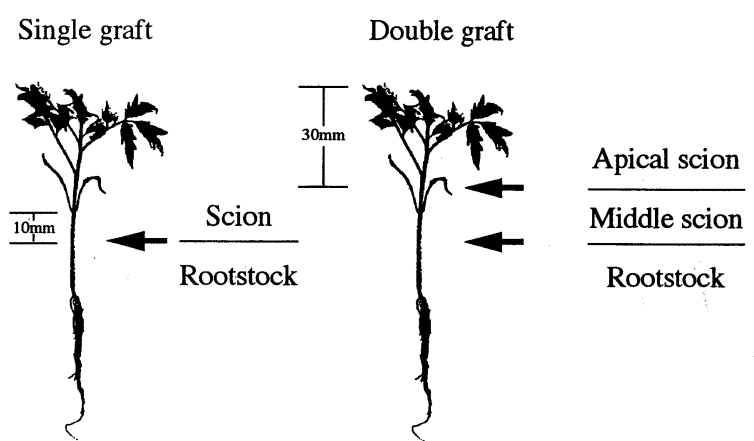

Fig. 1. Single and double grafts of tomato plants using tomato cultivars Oogata-Fukuju and LS-89 susceptible and resistant to bacterial wilt, respectively. Arrows show the positions of grafting.
Chisel-type approach grafts were carried out on 5week-old tomato plants at the two- or three-leaf stage. Rootstocks were topped $10 \mathrm{~mm}$ below their cotyledon, and the cuttings were used as scions (Fig. 1). Scion/ rootstock combinations of singly grafted plants were LS/OF, OF/LS, OF/OF and LS/LS. For double grafts, the second of which was carried out 1 week after the first, the middle scion contained their cotyledon. Apical scions were approximately $30 \mathrm{~mm}$ in length and included two or three leaves. Apical scion/middle scion/rootstock combinations of doubly grafted plants were LS/ $\mathrm{LS} / \mathrm{LS}, \mathrm{OF} / \mathrm{OF} / \mathrm{OF}, \mathrm{OF} / \mathrm{LS} / \mathrm{LS}, \mathrm{LS} / \mathrm{OF} / \mathrm{LS}, \mathrm{LS} / \mathrm{OF} / \mathrm{OF}$ and $\mathrm{OF} / \mathrm{LS} / \mathrm{OF}$. The junctions between graft and receptor were supported by a plastic clip (Superwith, Sakata). The grafted tomato plants were placed in an incubator at $25^{\circ} \mathrm{C}$ with $100 \%$ relative humidity for 4 days and then in a shaded room for 3 days.

Bioluminescent $R$. solanacearum YN5 $R$. solanacearum $\mathrm{OE} 1-1^{2)}$, a gift from Dr. H. Date, was triparentally transformed with plasmid pNP126 (Fig. $2)^{9,10)}$ via an intermediate host Escherichia coli HB101 harboring a helper plasmid pRK2013 for transconjugation. The triparental mating was performed by mixing cells in the late exponential phase ${ }^{13)}$. $R$. solanacearum transconjugants were screened on the selective agar media of Hara and $\mathrm{Ono}^{6)}$ containing kanamycin and tetracycline at $50 \mu \mathrm{g} / \mathrm{ml}$ and $20 \mu \mathrm{g} / \mathrm{ml}$, respectively. Kanamycin- and tetracycline-resistant clones were incubated overnight in PS media ${ }^{27)}$ containing kanamycin at $50 \mu \mathrm{g} / \mathrm{ml}$, diluted to $1.0 \times 10^{8} \mathrm{cfu} / \mathrm{ml}$ photometrically $\left(1.0 \times 10^{8} \mathrm{cfu} / \mathrm{ml}\right.$ had an optical density of 0.1 at $\left.600 \mathrm{~nm}\right)$ with the PS media containing kanamycin at $50 \mu \mathrm{g} / \mathrm{ml}$, then incubated at $25^{\circ} \mathrm{C}$ for $1 \mathrm{hr}$. Bioluminescence of each bacterial suspension was measured with a luminometer (Luminescence Reader, ALOKA).

Inoculation A single colony of the fluidal type $R$.

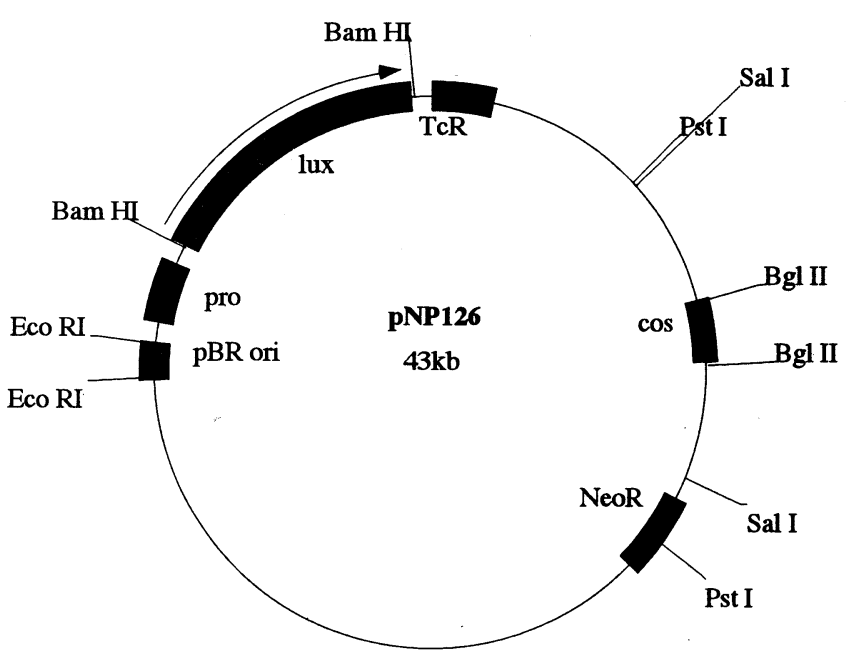

Fig. 2. Plasmid vector pNP126. pro, a promoter region derived from Burkholderia glumae; lux, lux operon derived from Vibrio fisheri; pBR ori, ori derived from $\mathrm{pBR} 322$; TcR, tetracyclineresistant gene; NeoR, neomycin-resistant gene. 
solanacearum transformants was grown at $30^{\circ} \mathrm{C}$ for $48 \mathrm{hr}$ on the selective agar medium of Hara and Ono containing kanamycin and tetracycline at $50 \mu \mathrm{g} / \mathrm{ml}$ and $20 \mu \mathrm{g} /$ $\mathrm{ml}$, respectively. The inoculum was incubated in PSmedium containing kanamycin at $50 \mu \mathrm{g} / \mathrm{ml}$, and the bacterial suspension was spectrophotometrically adjusted to $1.0 \times 10^{7} \mathrm{cfu} / \mathrm{ml}$. Roots of 25 tomato plants were dipped into the bacterial solution for $30 \mathrm{~min}$, then washed in flowing water for $1 \mathrm{~min}$. After inoculation, tomato plants were grown in water culture pots (diameter, $65 \mathrm{~mm}$; height, $65 \mathrm{~mm}$; Yamato Water Culture Pot No. 1, Yamato Plastic Co. Ltd.) in five times-diluted Hoagland's solution at $25^{\circ} \mathrm{C}$ in a growth chamber under $20,000 \mathrm{lux}$ for $12 \mathrm{hr}$ per day. Inoculation test had five replicates.

Bioluminescence in planta Bioluminescence was observed in all plants inoculated with YN5. Images of bioluminescence were obtained by focusing the VIM camera equipped with the ARGUS 50 (Hamamatsu Photonics) on the sample and exposing for $1 \mathrm{~min}^{9)}$. Images were superimposed on those obtained with incident light. Images were directly recorded in TIFF format at a PC workstation, for processing with Adobe Photoshop 4.0 and a Macintosh.

Bacterial population in tomato plants Roots of singly grafted OF/OF, LS/LS, LS/OF and OF/LS plants were dipped into $R$. solanacearum YN5 at $1.0 \times$ $10^{7} \mathrm{cfu} / \mathrm{ml}$. The middle and top of stems and collars were cut from five of each grafted plants 2, 6 and 10 days after inoculation (DAI) and macerated in a test tube (15 $\mathrm{mm}$ in diameter and $180 \mathrm{~mm}$ long) using an aluminum stick with $2 \mathrm{ml}$ sterile distilled water. The test tube was then incubated at $9^{\circ} \mathrm{C}$ for $16 \mathrm{hr}$. The original solution and its 10 -fold serial dilutions were dispensed in $0.1 \mathrm{ml} \mathrm{sam}$ ples and spread onto three plates of the selective agar

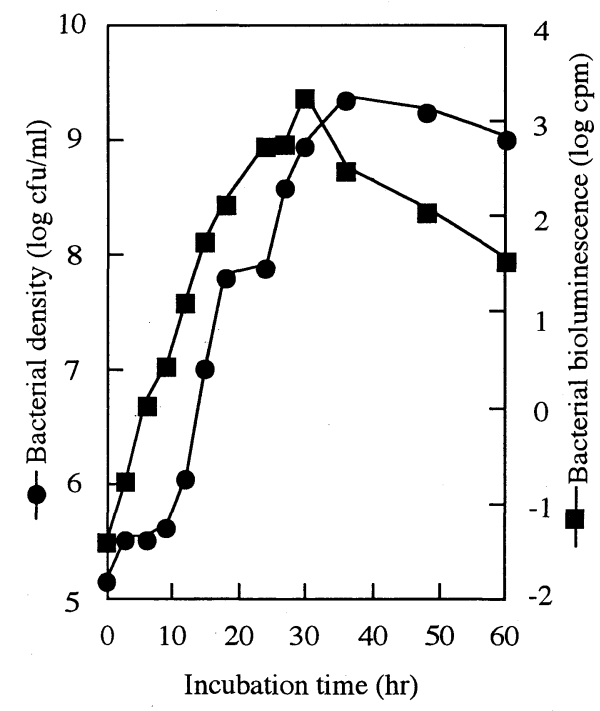

Fig. 3. Growth of Ralstonia solanacearum YN5 and the bioluminescence derived from the bacteria in a PS medium. Bacterial bioluminescence was measured with a luminescence leader. media of Hara and Ono and the media containing kanamycin at $50 \mu \mathrm{g} / \mathrm{ml}$. The number of colonies was counted 4 days after incubation at $30^{\circ} \mathrm{C}$ to estimate the population.

\section{RESULTS}

\section{Bioluminescent $R$. solanacearum YN5}

$R$. solanacearum transformants with pNP126 were screened for bioluminescence, plasmid maintenance and pathogenicity to OF plants. The intensity of bioluminescence of a transformant, YN5, in PS-media was 500 times as high as $E$. coli $\mathrm{HB} 101$ transformants carrying pNP126, and pathogenicity of the transformant was comparable to that of the parental strain $R$. solanacearum OE1-1. The transformant had high plasmid maintenance in antibiotics-free PS medium and in planta. Therefore, we used YN5 in further studies.

In the PS medium, the intensity of bioluminescence derived from YN5 increased from the lag phase to the stationary phase of bacterial growth (Fig. 3).

\section{The percentage of wilting plants}

OF plants inoculated with YN5 started to wilt 3 DAI, and all plants were severely wilted by 7 DAI. The percentage of wilting LS plants 15 DAI was $13.6 \%$ (Table 1).

Grafted plants in combinations of $\mathrm{OF} / \mathrm{OF}, \mathrm{LS} / \mathrm{OF}$, $\mathrm{OF} / \mathrm{OF} / \mathrm{OF}, \mathrm{LS} / \mathrm{OF} / \mathrm{OF}$ and $\mathrm{OF} / \mathrm{LS} / \mathrm{OF}$ were heavily wilted, and the percentage of wilting plants at $15 \mathrm{DAI}$ was above 80 (Table 1). About $90 \%$ of LS/LS, LS/LS/ LS and OF/LS/LS plants did not wilt, while about $50 \%$ of $\mathrm{OF} / \mathrm{LS}$ and LS/OF/LS plants wilted.

Table 1. The percentage of wilting plants in singly grafted and doubly grafted tomato plants in various combinations of the susceptible Oogata-Fukuju and the resistant LS-89 after inoculation with Ralstonia solanacearum $\mathrm{YN}^{\mathrm{a})}$

\begin{tabular}{lc}
\hline \multicolumn{1}{c}{ Plants $^{\mathrm{b})}$} & \% wilting plants $^{\mathrm{c})}$ \\
\hline Oogata-Fukuju (OF) & $98.1 \mathrm{~A}^{\mathrm{d})}$ \\
LS-89 (LS) & $13.6 \mathrm{D}$ \\
OF/OF & $100 \mathrm{~A}$ \\
LS/OF & $82.0 \mathrm{~B}$ \\
LS/LS & $11.1 \mathrm{D}$ \\
OF/LS & $52.2 \mathrm{C}$ \\
OF/OF/OF & $100 \mathrm{~A}$ \\
LS/OF/OF & $92.6 \mathrm{~A}$ \\
OF/LS/OF & $93.9 \mathrm{~A}$ \\
OF/LS/LS & $7.7 \mathrm{D}$ \\
LS/OF/LS & $50.0 \mathrm{C}$ \\
LS/LS/LS & $10.2 \mathrm{D}$ \\
\hline
\end{tabular}

a) Roots of plants were dipped into $R$. solanacearum YN5. For details, refer to the text.

b) Scion/rootstock or apical scion/middle scion/rootstock.

c) Assessed 15 days after inoculation.

d) D.M.R.T. $(p=0.05)$ 


\section{Behavior of bioluminescent $R$. solanacearum YN5 in planta}

Bioluminescence in the susceptible OF plants was first observed in the roots and collars 1 DAI (Fig. 4-1). The intensity of bacterial bioluminescence in the collar reached a maximum 7-8 DAI and thereafter decreased. In the middle and the top of the stem, bioluminescence was first observed $4 \mathrm{DAI}$ and reached a maximum $8 \mathrm{DAI}$. Thereafter, it decreased and was not observed at all at 15 DAI. On the other hand, bioluminescence in the resistant LS plants was only observed in the roots and collars (Fig. 4-1).

In singly grafted OF/OF and LS/LS plants, bacterial bioluminescence was similar to that in OF plants and LS plants, respectively (Fig. 4-2). In LS/OF plants, bioluminescence in the rootstocks was first observed 1 DAI and reached a maximum by 7-8 DAI. Bioluminescence was then observed in the scions, and the plants wilted heavily. In OF/LS plants, bioluminescence in the rootstocks remained weak. Then the plants in which bioluminescence had reached a maximum in the scions 7-8 DAI wilted heavily. On the other hand, the plants in which bioluminescence was not observed in the scions did not wilt.

In doubly grafted $\mathrm{OF} / \mathrm{OF} / \mathrm{OF}$ and LS/OF/OF plants with the susceptible OF used as the middle scions and the rootstocks, bioluminescence was strong in the rootstocks and then in the middle scions, and the plants wilted heavily (Fig. 4). In LS/LS/LS and OF/LS/LS plants with the resistant LS used as the middle scions and the rootstocks, weak bioluminescence was observed only in the roots and collars similar to that in the resistant LS plants. In OF/LS/OF plants, bioluminescence was strong in the rootstocks but weak in the middle scions, and then was strong in the apical scions, and the plants wilted heavily. In LS/OF/LS plants, weak bioluminescence was first observed in the rootstocks, and the plants with strong bioluminescence in the middle scion wilted heavily.

\section{Bacterial population in tomato plants}

The population of kanamycin-resistant $R$. solanacearum increased by an order of 3 to 4 in both the scions and the rootstocks of $\mathrm{OF} / \mathrm{OF}$ plants and reached $2.5 \times$ $10^{8}$ and $1.4 \times 10^{9} \mathrm{cfu} / \mathrm{g}$, respectively (Table 2 ). The bacterial population in LS/LS plants did not change much remaining at $10^{3}-10^{4} \mathrm{cfu} / \mathrm{g}$ in the scion and $10^{5}-10^{6} \mathrm{cfu} / \mathrm{g}$ in the rootstocks. The bacterial populations in LS/OF and OF/LS plants resembled those in the OF/OF and LS/LS plants, respectively. It should be noted that bacteria were present in the scions of non-wilting OF/ LS plants at $10^{3}$ to $10^{4} \mathrm{cfu} / \mathrm{g}$. The presence or absence of kanamycin did not affect the assessment of the bacterial populations (data not shown); bioluminescence was emitted from all colonies obtained on kanamycin-free medium and kanamycin-containig medium.
$\mathbf{O F}$

1

ISS

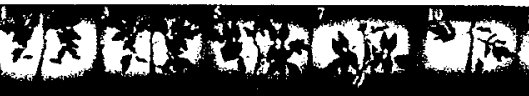

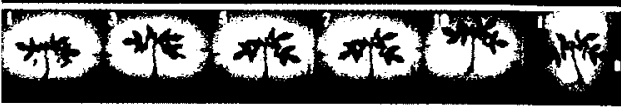

2

OF/OF

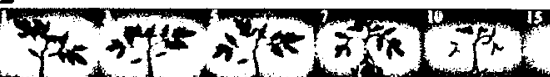

ISS/OF

LS/LS

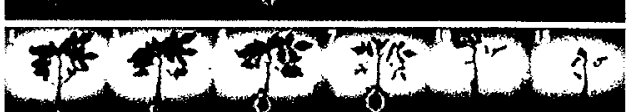
(1)

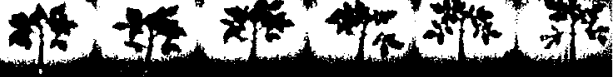

OF/LS

(Non-wilting)

OF/LS

(Wilting)
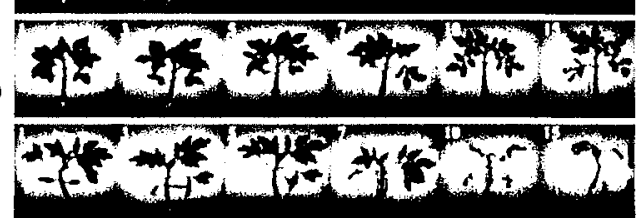
3

LS/OF/OF

OF/LS/OF

3
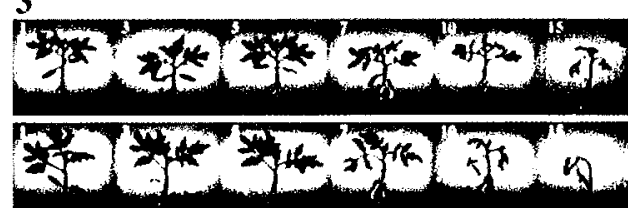

OF $/ \mathrm{LS} / \mathrm{LS}$

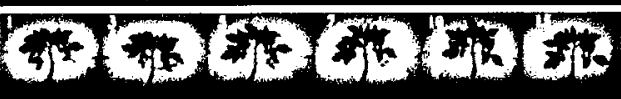

LS/OF/LS

(Non-wilting)

LS/OF/LS

(Wilting)

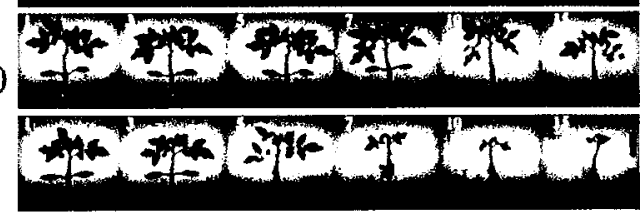

Fig. 4. Bioluminescence of Ralstonia solanacearum YN5 in tomato plants after inoculation with $R$.

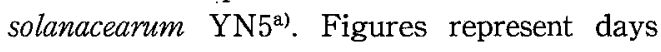
after inoculation. For details, refer to the text. 1. Bioluminescence in tomato cultivars OogataFukuju (OF) and LS-89 (LS). 2. Bioluminescence in grafted tomato plants in various scion/rootstock combinations of OF and LS. 3. Bioluminescence in double grafted tomato plants in various apical scion/middle scion/rootstock in combinations with OF and LS.

\section{DISCUSSION}

There are many reports on the behavior of $R$. solanacearum in host plants, but these previous results were obtained using methods which disrupted host tis* sues or depended on selective media. The disruption of plant tissues does not allow subsequent examination of the bacterial behavior and the disease development in the same plant tissues. Results from the present study using the VIM camera and the ARGUS 50 as a luminescence detection technique demonstrate that the relative intensity of bioluminescence derived from the genetically engineered bioluminescent bacteria YN5 was positive- 
Table 2. Population of Ralstonia solanacearum YN5 in singly grafted tomato plants in various combinations with the susceptible Oogata-Fukuju (OF) and the resistant LS-89 (LS)

\begin{tabular}{cllccc}
\hline \hline \multirow{2}{*}{ Plants $^{\text {a) }}$} & \multirow{2}{*}{ Symptom $^{\text {b) }}$} & Parts & \multicolumn{3}{c}{ Population of YN5 $(\mathrm{cfu} / \mathrm{g})$} \\
\cline { 3 - 5 } & & & 2 days $^{\mathrm{c})}$ & 6 days & 10 days \\
\hline OF/OF & Wilting & Scion & $(2.6 \pm 1.6) \times 10^{4 \mathrm{~d})}$ & $(2.5 \pm 0.21) \times 10^{8}$ & $(7.5 \pm 3.0) \times 10^{9}$ \\
& & Rootstock & $(1.6 \pm 1.5) \times 10^{5}$ & $(1.4 \pm 0.50) \times 10^{9}$ & $(1.9 \pm 0.28) \times 10^{9}$ \\
LS/LS & Non-wilting & Scion & $(2.5 \pm 1.3) \times 10^{3}$ & $(2.6 \pm 0.85) \times 10^{4}$ & $(1.0 \pm 0.071) \times 10^{3}$ \\
& & Rootstock & $(3.5 \pm 2.9) \times 10^{5}$ & $(6.7 \pm 1.9) \times 10^{5}$ & $(2.3 \pm 2.5) \times 10^{6}$ \\
LS/OF & Wilting & Scion & $(3.5 \pm 1.9) \times 10^{3}$ & $(7.7 \pm 0.49) \times 10^{7}$ & $(8.9 \pm 1.6) \times 10^{9}$ \\
& & Rootstock & $(4.9 \pm 4.2) \times 10^{5}$ & $(3.9 \pm 4.6) \times 10^{9}$ & $(1.6 \pm 0.92) \times 10^{9}$ \\
OF/LS & Non-wilting & Scion & $(6.0 \pm 1.4) \times 10^{3}$ & $(2.1 \pm 0.14) \times 10^{4}$ & $(1.2 \pm 0.49) \times 10^{3}$ \\
& & Rootstock & $(2.1 \pm 2.7) \times 10^{5}$ & $(3.5 \pm 2.8) \times 10^{6}$ & $(8.9 \pm 0.19) \times 10^{5}$ \\
& Wilting & Scion & - & - & $(8.2 \pm 5.2) \times 10^{9}$ \\
& & Rootstock & - & - & $(6.0 \pm 2.0) \times 10^{6}$ \\
\hline
\end{tabular}

a) Scion/rootstock.

b) Symptoms were observed 10 days after inoculation. For other conditions, refer to the text.

c) Days after inoculation with $R$. solanacearum YN5.

d) Means $\pm \mathrm{SE}$ of five replicates.

ly correlated with the growth of bacteria both on the PS medium from the lag to the stationary phase and within the tomato plants. Therefore, bioluminescent YN5 and this luminescence detection technique can be used to study the relationship of bacterial behavior and disease development of bacterial wilt in the same plant without destroying the samples.

The most widespread control strategy against bacterial wilt is the use of resistant cultivars ${ }^{1,14,18,24,25)}$. Disease resistance of grafted plants is generally attributed to the absence of bacterial colonization in the resistant cultivars $^{8)}$, but latent infections were demonstrated in bacterial wilt-resistant cultivars ${ }^{5}$. Resistance to bacterial wilt is not associated with inhibition of bacterial root invasion but with the ability of the plant to limit bacterial colonization in the stem $^{4}$. . Since bacterial colonization in the vascular tissues of the stem correlated with the frequency of bacterial wilt in the field, the level of resistance appears to correlate with the limitation of bacterial spread in plants ${ }^{4,19)}$.

Grimault and Prior have reported the importance of bacterial latent infections in tomato xylem vessels ${ }^{5}$. Vasse et al. ${ }^{26)}$ have reported that after colonization in exudation sites such as root extremities and the axils of secondary roots, the bacteria intercellularly infect the inner cortex and the vascular parenchyma. Following infection, the bacteria invaded the protoxylem vessels. The results in this study show that tomato plants, either resistant LS or susceptible OF, in which the bacteria spread into the upper stems following a high proliferation of bacteria in the roots and the collars, would wilt. The root and the collars in non-wilting plants are latently infected with the bacteria.

Our previous studies revealed that the bacteria grow not only in the xylem vessels but also in the intercellular spaces and the inner spaces between the epidermis and the cortex in wilting tomato plants ${ }^{9}$. In addition, a quantitative difference in bacterial bioluminescence between susceptible tomato cultivars and resistant ones inoculated with YN5 could be more distinctly observed in the upper stems than in the collars of tomato plants ${ }^{17}$. Bacterial proliferation in the roots and collars and the subsequent spread of the bacteria into the upper stems are crucial factors for the development of bacterial wilt in the tomato plants.

Grimault and Prior ${ }^{5)}$ have reported that resistant scions grafted onto susceptible rootstocks wilted and have suggested that vascular tissues of resistant cultivars are not as tolerant to higher bacterial populations as are susceptible ones and that resistance is correlated with the limitation of bacterial spread in the lower part of the stem. Nakaho et $a l .{ }^{16)}$ suggested that bacterial wilt of susceptible scions grafted on resistant rootstocks is due to the movement of the bacteria from latently infected rootstocks into the scions. Multiple genes contribute to the resistance in LS to bacterial wilt. The resistance quantatively controls disease development, depending on enviroment factors such as the pathogen density, cultivation condition and so on ${ }^{8}$.

In the present study, the percentage of wilting $\mathrm{OF} /$ LS/LS plants was equal to that of wilting LS and LS/LS plants, and bacterial bioluminescence in OF/LS/LS plants was very similar to that in the LS and LS/LS plants.

Resistance of LS results from the suppression of bacterial proliferation in the roots and the stems below the first leaf. Moreover, in the susceptible scions of about $50 \%$ of the OF/LS and LS/OF/LS plants using LS as the rootstocks, the bacteria latently infected the rootstocks. Movement into the scions did not lead to a large increase in the bacterial population, and the grafted plants did not wilt. Taking these results together, supression of the bacteria proliferation in the roots and the stems below the first leaf of resistant rootstocks affect bacterial growth in the susceptible scions and the quantative control of resistance against development of the disease. 
We wish to thank Dr. H. Date for providing the bacterial strain, Drs. C. I. Kado, M. Horikoshi and T. Hirooka for providing the plasmids and Dr. K. Maeda for valuable suggestion.

\section{Literature cited}

1. Buddenhagen, I.W. and Kelman, A. (1964). Biological and physiological aspects of bacterial wilt caused by Pseudomonas solanacearum. Annu. Rev. Phytopathol. 2 : 203-230.

2. Date, H., Nasu, H. and Hatamoto, M. (1993). Thermal death range of Pseudomonas solanacearum under various condition. Ann. Phytopathol. Soc. Jpn. 59 : 709-713.

3. Enfinger, J.M., MacCarter, S.M. and Jaworski, C.A. (1979). Evaluation of chemicals and application methods for control of bacterial wilt of tomato transplants. Phytopathology 69 : 637-640.

4. Grimault, V. and Prior, P. (1993). Bacterial wilt resistance in tomato associated with torerance of vascular tissues to Pseudomonas solanacaerum. Plant Pathol. 42 : 589-594.

5. Grimault, V. and Prior, P. (1994). Grafting tomato cultivars resistant or susceptible to bacterial wilt: analysis of resistance mechanisms. J. Phytopathol. 141 : 330-344.

6. Hara, H. and Ono, K. (1983). Ecological studies on the bacterial wilt of tobbaco, caused by Pseudomonas solanacearum E. F. Smith. I. A selective medium for isolation and detection of Pseudomonas solanacearum. Bull. Okayama Tob. Exp. Stn. 42 : 127-138.

7. Hayakawa, T., Kinoshita, K., Miyaki, S., Fujiwake, H. and Ohsuka, S. (1986). Ultra-low-light level camera for photon counting imaging. Photochem. Photobiol. 43 : 9597.

8. Hayward, A.C. (1991). Biology and epidemiology of bacterial wilt caused by Pseudomonas solanacearum. Annu. Rev. Phytopathol. 29 : 65-87.

9. Hikichi, Y., Nasu, Y., Toyoda, K., Suzuki, K., Horikoshi, M., Hirooka, T. and Okuno, T. (1998). Behavior of bioluminescent Ralstonia solanacearum YN5 containing the luxCDABE in tomatoes susceptible and resistant to bacterial wilt. In Bacterial Wilt Disease (Prior, P.H., Allen, C. and Elphinstone, J. eds.), Springer, Heidelberg, pp. 233-242.

10. Hikichi, Y., Suzuki, K., Toyoda, K., Horikoshi, M., Hirooka, T. and Okuno, T. (1998). Successive observation of growth and movement of genetically lux-marked Pseudomonas cichorii and the response of host tissues in the same lettuce leaf. Ann. Phytopathol. Soc. Jpn. 64 : 519-525.

11. Kelman, A. and Sequeira, L. (1965). Root-to-root spread of Pseudomonas solanacearum. Phytopathology 55: 304-309.

12. Maly, F.E., Urwyler, A., Rolli, H.P., Dahinden, C.A. and De Weck, A.L. (1988). A single-photon imaging system for the simultaneous quantitation of luminescent emissions from multiple samples. Anal. Biochem. 168 : 462469.

13. Maniatis, T., Fritsch, E.F. and Sambrook, J. (1982). Molecular Cloning : A Laboratory Manual, Cold Spring
Harbor Laboratory, Cold Spring Harbor, New York.

14. Monma, S. and Sakata, Y. (1993). Inheritance of resistance to bacterial wilt in tomato. In Bacterial Wilt. Proceedings of an International Symposium (Hartman, G.L. and Hayward, A.C. eds.), Kaohsiung, Taiwan. ACIAR Proc. 45 : 149-153.

15. Nakaho, K. (1997). Distribution and multiplication of Ralstonia solanacearum (synonym Pseudomonas solanacearum) in tomato plants of resistant rootstock cultivar LS-89 and susceptible Ponderosa. Ann. Phytopathol. Soc. Jpn. 63: 83-88.

16. Nakaho, K., Takaya, S. and Sumida, Y. (1996). Conditions that increase latent infection of grafted or nongrafted tomatoes with Pseudomonas solanacearum. Ann. Phytopathol. Soc. Jpn. 62: 234-239.

17. Nakazawa-Nasu, Y., Kitanosono, S., Suzuki, K., Hikichi, Y. and Okuno, T. (1999). A new method for the selection of tomato plants resistant to bacterial wilt using bioluminescence from lux-marked Ralstonia solanacearum. Ann. Phytopthol. Soc. Jpn. 65 : 470-474.

18. Peregrine, W.T. and Ahmad, K.B. (1982). Grafting-a simple techninque for overcoming bacterial wilt in tomato. Trop. Pest. Man. 28 : 71-76.

19. Prior, P., Bart, S., Leclercq, S., Darrasse, A. and Anais, G. (1996). Resistance to bacterial wilt in tomato as discerned by spread of Pseudomonas (Burkholderia) solanacearum in the stem tissues. Plant Pathol. 45 : 720726.

20. Prosser, J.I., Killham, K., Glover, L.A. and Rattray, E.A. S. (1996). Luminescence-based systems for detection of bacteria in the environment. Crit. Rev. Biotechnol. 16 : 157-183.

21. Schmit, J. (1978). Microscopy of early stages of infection by Pseudomonas solanacearum E.F.S. on 'in vitro' grown tomato seedlings. In Proceedings of the 4th International Conference on Plant Pathogenic Bacteria, INRA, Angers, France, pp. 841-856.

22. Shaw, J.J. and Kado, C.I. (1986). Development of a Vibrio bioluminescence gene-set to monitor phytopathogenic bacteria during the ongoing disease process in a non-disruptive manner. Bio/Technology 4 : 560-564.

23. Suzuki, S., Usa, M., Nagoshi, T., Kobayashi, M., Watanabe, N., Watanabe, H. and Inaba, H. (1991). Two-dimensional imaging and counting of ultraweak emission patterns from injured plant seedlings. J. Photochem. Photobiol. Biol. 9 : 211-217.

24. Thurston, H.D. (1976). Resistance to bacterial wilt (Pseudomonas solanacearum). In Proceedings of an International Planning Conference and Workshop on the Ecology and Control of Bacterial Wilt Caused by Pseudomonas solanacearum (Sequeira, L. and Kelman, A. eds.), NC State University, Raleigh, pp. 58-62.

25. Tikoo, S.K., Mathal, P.J. and Kishan, R. (1979). Successful graft culture of tomato in bacterial wilt sick soils. Curr. Sci. 48 : 259-260.

26. Vasse, J., Frey, P. and Trigalet, A. (1995). Microscopic studies in intercellular infection and protoxylem invasion of tomato roots by Pseudomonas solanacearum. Mol. Plant-Microbe Interact. 8: 241-251.

27. Wakimoto, S., Uematsu, T. and Mukoo, H. (1968). Bacterial canker disease of tomato in Japan. 1. Isolation 
and identification of the causal bacteria, and resistance of tomato varieties against the disease. Bull. Natl. Inst. Agric. Sci. Ser. C. $22:$ 269-279.

28. Yamakawa, K. (1978). Cultivar resistance to Pseudomonas solanacearum in tomato and eggplant. Plant Prot. $32: 197-200$.

\section{和 文 摘 要}

曳地康史・中澤（那須）佳子-北之園忍・鈴木一実-奥野哲郎： 青枯病抵抗性と感受性トマト品種による接木トマトにおける lux 標識 Ralstonia solanacearum の挙動

Vibrio fisheri 由来の lux オペロンと Burkholderia glumae ゲノム DNA 由来のプロモーター領域を有する pNP126で Ralstonia solanacearum OE1-1 を形質転換し, in vitro での誘 導期から定常期にかけての増殖能と生物発光に正の相関関係を
示し, OE1-1 と同等の病原性を示す YN5 を得た。青枯病抵抗性 品種 LS-89 と感受性トマト品種 大型福寿の接木卜マトにおけ る YN5 由来の生物発光と青枯病の発病について画像解析シス テムARGUS50を装着したVIM カメラを用いて経時的に観察 した。根と地際部における $R$. solanacearum 増殖量の程度が青 枯病発病に重要な要因であり, LS-89 の青枯病に対する抵抗性 は，第一葉下の $R$. solanacearum の増殖抑制に起因することが 明らかとなった。LS-89 を子葉下の台木として, 大型福寿を穂木 として用いた接木トマトでは，R. solanacearum はいずれの接 木トマトの台木においても潜在感染しており, 未発病の接木卜 マトの穂木からも $R$. solanacearum は検出された。一方, $R$. solanacearum が穂木で著しく増殖した接木卜マトはすべて萎 调・枯死した。すなわち, 抵抗性台木 LS-89 の R. solanacaerum に対する何らかの増殖抑制機能が, 感受性穂木大型福寿におけ る $R$. solanacearum の増殖にも影響を及ぼし, 青枯病の発病率 を量的に調整していることが示唆された。 